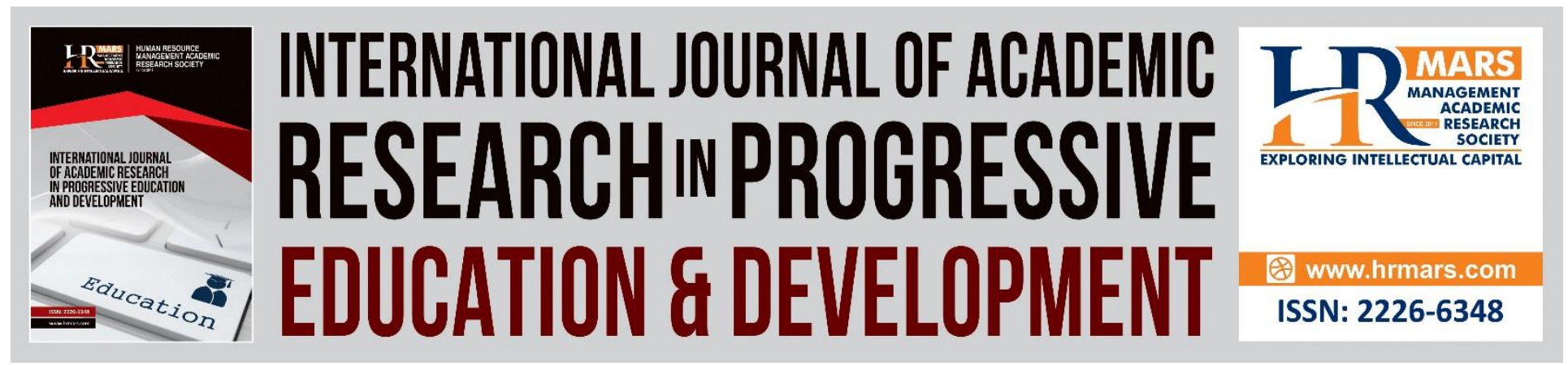

\title{
Compound Chunk: Telegram Autobot Quiz to Improve Spelling on Compound Nouns
}

\author{
Siti Fadiah Abu Bakar, Faten Hanani Fauzi, Nur Faiqah Mohd Yasin, \\ Melor Md Yunus
}

To Link this Article: http://dx.doi.org/10.6007/IJARPED/v8-i1/5498

DOI: $10.6007 /$ IJARPED/v8-i1/5498

Received: 25 Dec 2018, Revised: 28 Jan 2019, Accepted: 11 Feb 2019

Published Online: 18 Feb 2019

In-Text Citation: (Bakar, Fauzi, Yasin, \& Yunus, 2018)

To Cite this Article: Bakar, S. F. A., Fauzi, F. H., Yasin, N. F. M., \& Yunus, M. M. (2018). Compound Chunk:

Telegram Autobot Quiz to Improve Spelling on Compound Nouns. International Journal of Academic

Research in Progressive Education and Development, 8(1), 48-63.

Copyright: (C) 2019 The Author(s)

Published by Human Resource Management Academic Research Society (www.hrmars.com)

This article is published under the Creative Commons Attribution (CC BY 4.0) license. Anyone may reproduce, distribute, translate and create derivative works of this article (for both commercial and non-commercial purposes), subject to full attribution to the original publication and authors. The full terms of this license may be seen

at: http://creativecommons.org/licences/by/4.0/legalcode

Vol. 8, No. 1, 2019, Pg. 48 - 63

http://hrmars.com/index.php/pages/detail/IJARPED

JOURNAL HOMEPAGE

Full Terms \& Conditions of access and use can be found at http://hrmars.com/index.php/pages/detail/publication-ethics 


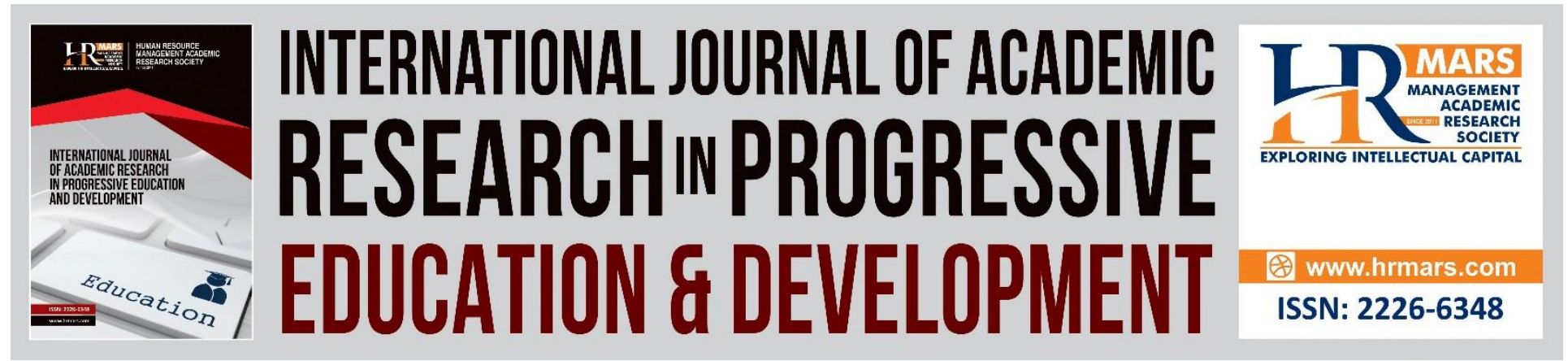

\title{
Compound Chunk: Telegram Autobot Quiz to Improve Spelling on Compound Nouns
}

\author{
Siti Fadiah Abu Bakar \\ SK Kem Terendak 1, Melaka, Malaysia \\ Email: fadiah93@gmail.com \\ Faten Hanani Fauzi \\ SK Jalan 3, Selangor, Malaysia \\ Email: fatenhanani3893@yahoo.com \\ Nur Faiqah Mohd Yasin \\ SK Seri Iskandar, Perak, Malaysia \\ Email:freakyfaie@gmail.com \\ Melor Md Yunus \\ Faculty of Education, Universiti Kebangsaan Malaysia \\ Email: melor@ukm.edu.my
}

\begin{abstract}
The importance of integrating mobile technology in assisting language learning is becoming more popular in the learning of ESL. Telegram is one of the messaging applications that is not as widely used as other messaging applications and can actually be used as an educational tool. Therefore, this is an action research focuses on improving the pupils' spelling skills in compound nouns words through the usage of Telegram Autobot Quiz. The participants of this research were 30 Year 5 pupils from three primary schools in three different states of Bandar Baru Bangi,Selangor , Seri Iskandar,Perak and Alor Gajah,Melaka. The "Compound Chunk" through Telegram Autobot Quiz had been used as intervention method in improving pupils' spelling compound nouns. Pupils were required to play quiz on "Two Pictures One Word", "One Picture One Word" lastly two rebus activities as post-test. The findings of the research were analysed qualitatively using the Triangulation method of observation's checklist, interview and document analysis. The findings indicated that there had been an improvement in the participants' spelling performance after the intervention and gave positive opinions concerning the use of the quiz. In conclusion, the quiz
\end{abstract}


International Journal of Academic Research in Progressive Education and Development Vol. 8, No. 1, 2019, E-ISSN: 2226-6348 @ 2019 HRMARS

can be extended by adding more words of various contents benefited on the use of messaging apps as $21^{\text {st }}$ Century teaching aid in written spelling.

Keywords: Spelling skill, compound nouns, Compound Chunk, improvement, messaging application

\section{Introduction}

The Primary School Standard Curriculum (KSSR) has been implemented in Malaysian Education System in 2011 with the aim to enhance the pupil's English language (Mohamed, 2007). According to Year 4 KSSR's English document standard, the goal of the English language curriculum is to help pupils acquire the language in order to help them use it in their daily lives, to further their studies and for work purposes (Ministry of Education, 2012). Yet, the acquisition and learning process will be impeded if the pupils could not understand English vocabulary and have limited number of vocabularies. Hammer (2007) explained that teaching vocabulary does not only teach new meaning of words but also teach how to spell and how to pronounce the words. Teaching vocabulary in the early English learning is very important. Students will find difficulties in learning English if they lack of vocabulary. Thus, teaching vocabulary and spelling for young learners was not easy. Westwood (2014) stated that teaching spelling was quite difficult because there were thousand hundreds words in English. The teacher had to introduce new words and asked the students to practice spelling, making clear the meanings and the ways in which each can be used.

Spelling problem may affect the writing skills because when the students write down the words wrongly, it may lead in the wrong spelling. Meaning that, they will implement the knowledge that they know wrongly in their learning process. It will totally affect their understanding of the words and get confuse with the words that they learned. It is called as misspelled the words as mentioned by (Lesley Lanir, 2011). She mentioned that misspelled words could destabilize memories of correct word forms, creating confusion and regression in a student's spelling ability. Hence, the wrong information written occurred because of the incorrect spelling of the words. As an educator, we have to make sure that the information given to students was totally correct because we want to avoid this situation to occur. A compound word is formed when two or more words join to form a new word that has its own meaning. Although compound words are often written as single words such as teapot), sometimes they are not. That's why it is important to understand that through spelling, this confusion can be avoided.

Mobile Technologies are portable and handheld devices that are used in everyday life. These technologies are used by a large number of people in the different fields of life and for different purposes; however, nowadays, mobile technologies have been integrated in educational contexts. Accordingly, mobile technology is considered as a teaching and learning material both within and beyond the classroom. According to Lan and Sie (2010), Learning through mobiles allows learners to obtain and acquire knowledge and learning materials, anywhere, anytime and this is by the use of mobile technologies and internet. In particular, the functions available through Information and Communication Technologies (ICT) have increased and developed through time and in accordance to the needs of the learners and the utility of these devices and their implementation in their learning process. Besides, these technologies are given the 
popularity, affordability, portability and flexibility of such devices. Thus, it is not surprising that educators have considered these devices beyond the classroom for educational purposes (Crippen \& Brooks, 2000; Liu, 2007; Motiwalla, 2007).

Through preliminary investigation, pupils seemed to be struggling to build simple sentences as they had limited range of vocabulary and eventhough they know the words but they did not know how to spell them thus they have to ask the teacher to help them spell the words.

In this study, Compound Chunk via Telegram Autobot is used as a platform to improve the pupils' spelling skill of compound nouns. This study aims to investigate to what extent the Compound Chunk via Telegram Autobot helps in improving pupil' spelling skill of compound nouns and whether or not the pupils' spelling be improved by using the Compound Chunk via Telegram Autobot. Thus, selected pupils were chosen to undergo a series of intervention. Through the intervention, it is determined whether or not Compound Chunk via Telegram Autobot can improve the pupils' spelling skill of compound nouns.

\section{Literature Review}

This study revolved around the intervention in improving the pupils' spelling skill using mobile technology namely the instant messaging application. It is focused on their spelling in writing rather than oral spelling as that was what exactly mentioned in the standard document of writing skill. It was mentioned that, pupils would master the mechanics of writing and then learn to write in words, phrases and sentences level (Bahagian Pembangunan Kurikulum, 2011). Language convention skills are important in compositional writing, with spelling appearing to be particularly important (Berninger, 2002). However, before they could master the whole mechanics of writing, they should be able to write the words correctly without any spelling errors. In this case, it is strongly believed that by improving the pupil's spelling skill earlier, it would lead to the perfection of the other mechanics of writing. In other words, before preparing the pupils towards constructing perfect sentences, they should be able to be really good in spelling out the words.

This study also focused on improving the pupils spelling on compound noun, which were commonly required in writing exercises. It had been improved by implementing teaching spelling using pictures incorporating in games as to have fun learning process in non-stressful environment. It is believed pictures are one of the tools that have been claimed by many scholars as helpful tool in assisting the pupils to enrich their ability to spell words. By using pictures, it was proven that it helped pupils to imagine the meaning of the words and made it easier for them to recall and spell those words (Harmer, 2007). Gower, Phillips and Walters (2007) admitted that "pictures often illustrate meaning more directly and quickly than through verbal explanation and they can help to make the associated language memorable". Here, it indicates that the uses of pictures were helpful to retain the pupils' memory plus arouses their interest to spell the words. Furthermore, according to Andrea Bennett (2011) language games are powerful where play to facilitate deep and meaningful learning where pupils enjoy learning via having a sense of their own progression and where the learning is relevant and appropriate. According to Skinner"s Language Acquisition Theory, playing language game can be presented as a kind of prize after learning which allows teachers to motivate learners to step forward (Miller and Pound, 2010). 
Piaget also supported the significance of playing due to its contribution to the development of problem solving, creativity, and communication, which happens naturally in the process of playing language games (Sylvin, 2009). Concurrent with Vygotsky"s viewpoint, one of the aims of the current study was to make spellers aware that they do possessed higher-level mental orthographic skills, such as visual imaging, that they can successfully use to enhance their spelling ability. In addition, I also considered Gardner's (2004) "Theory of Multiple Intelligences" in the development of a visual imagery programme. Gardner (2004) stated that learners could become more successful in all subject areas, including the learning of basic skills, if they have the opportunity to learn through their strengths.

In the context of the medium used for the intervention, telegram automated bot is used to create an automatic compound nouns quiz. Telegram automated bot allows the user to type answers and received instant reply. According to (Pushkash (2016), automated chatbot platforms are ideal environments for creating assessments. They provide you with immediate respond and with the feature that the instant messaging applications can be accessed any time of the day, students will able to adapt their learning schedule. It was not surprising for them to see incorporation of social tools such as instant messaging and texting into their academic studies because instant messaging applications are convenient and practical for nowadays communication (Lauricella and Kay, 2013). Thus, the combination of pictures with the spelling game - Compound Chunk via Telegram Autobot have created fun and meaningful to the pupils. Pupils enjoy spelling game and they become more active learners as Dogg (2012) mentioned that games could create a comfortable and friendly atmosphere. Pupils also need to visualise the words in their mind before they spell the words correctly.

\section{Research Design}

The study is an action research using a qualitative method research design in order to gain insight and explore the depth of the problem. This is based on Kemmis and McTaggart's (1988) action research model. According to Burns (2005), Kemmis and McTaggart had introduced a spiral model, which consists of four important steps in action research, which are plan, act, observe and reflect. The rationale behind selecting qualitative method research design is because it is a systematic subjective approach used for understanding views and perceptions. It offers visions to different problems and helps in developing concepts or theories for potential research. This method can capture expressive information about beliefs, values, feelings, and motivations that underlie behaviors. In addition, this method is appropriate for practical situations in which a fuller understanding of behavior is applied.

\section{Respondents}

The participants of this research were 30 Year 5 pupils from three primary schools in three different states of Bandar Baru Bangi, Selangor, Seri Iskandar, Perak and Alor Gajah, Melaka. The participants were selected based on their low scores compared to their other classmates during the spelling bee activity conducted, as well as the mistakes spotted in the writing worksheets given to them during English teaching and learning sessions. The research participants were all Malays and all of them came from families with similar socio - economic backgrounds. In addition, they were only familiar with English language in school and they were not using English language 
in their daily conversation as well as not listening to English songs or watching English cartoons. After the spelling activities were conducted, the selected participants were instructed to use Compound Chunk, the Telegram Autobot Quiz. After that, teacher would evaluate the students using another spelling exercise.

\section{Instrumentation}

This study also focused on improving the pupils spelling on compound noun, which were commonly required in writing exercises. It had been improved by implementing teaching spelling using instant messaging application automated quiz bot to have a fun learning process in nonstressful environment. The automated quiz bot can be used as a conversational partner when learning language where it could allow the pupil to practice their language skills anytime, and would not mind repeating the same materials several times (Roos, 2018). The instant messaging application automated quiz contains pictures questions where it believed picture is one of the tools that have been claimed by many scholars as helpful tool in assisting the pupils to enrich their ability to spell words. By using pictures, it was proven that it helped pupils to imagine the meaning of the words and made it easier for them to recall and spell those words (Harmer, 2007). Gower, Phillips and Walters (2007) admitted that "pictures often illustrate meaning more directly and quickly than through verbal explanation and they can help to make the associated language memorable". Here, it indicates that the uses of pictures were helpful to retain the pupils' memory plus arouses their interest to spell the words. Furthermore, according to Andrea Bennett (2011) language games are powerful where play to facilitate deep and meaningful learning where pupils enjoy learning via having a sense of their own progression and where the learning is relevant and appropriate. Thus, pupils enjoy the ompound Chunk autobot quiz game as they need to visualise the words in their mind before they spell the words correctly.

\section{Data Collection}

The data is tabulated using three instruments, which are observation, document analysis, and interview. This observation would be applied based on the pupils' performances in terms of behavior and attitudes, achievement and the pupils' participation. Through this observation, researchers could see the improvements from a slow learner to the active learner which would help them to build their understanding as stated by Johnson (2008) where he said that observation would help towards the methodical and tactical improvisation in order to develop a full understanding of the setting of interest. So, this observation would help researchers to find the problems of the pupils and improve them.

Document analysis is a record taken from the pupils such as their homework and exercise. Researchers might prepare the tasks according to the topic that they had learned. It could help the pupils to improve their knowledge because they were always practicing themselves in finishing all the tasks. Based on Ting Leng Seong, Ahmad Sabry, and Ting Hun Yong (2013), they stated that a selected document should be relevant to the topic being studied so that the information has high validity to use it as support materials. That means, researchers needed to prepare the tasks related to the topic that was going to be implemented during the research. Researchers would use this method of data collection in order to use pupils' progress in spelling 
skills. According to Bowen (2009), the advantages of using document analysis that grounded in local setting often reliable and valid plus easy to analyse.

According to Fraenkel, Wallen and Hyun (2015), interview was one of the most widely used and basic methods for obtaining qualitative data. Noor (2013) stated that interview is a conversation with a purpose. Hence, interview was used to gather data from the research participants about their feelings, beliefs and opinions about certain situation based on their own words. By interviewing them, researchers were able to get information that might not be obtained through their work.

\section{Data Analysis}

The findings of the research were written based on the two research questions which are; i) Can the pupils' spelling be improved by using the Compound Chunk via Telegram Autobot and ii) To what extent the Compound Chunk via Telegram Autobot helps in improving pupil' spelling skill of compound nouns. All the data were collected based on three data collection method, which are observation, document analysis, and interview. Observation was a fundamental and highly important method to all qualitative inquiry (Marshall, 2006). It was the recommended data that can be used in collecting the data. Checklist is used as an observation of the pupils' performances. This checklist helped to find the improvement of the pupils' along the session. It was used to monitor the pupils' attitude, achievements and participation of the pupils' themselves. Throughout this research, researchers found a pupil who could not give fully attention to the intervention and tended to disturb his friends. Fortunately, all of them performed well along the sessions especially when given rewards for their effort. An observation checklist was designed which could evaluate the impact of using Compound Chunk towards pupils. The checklist will be tick or cross for before intervention and after intervention. The accumulated data will be tabulated in a table.

Analysis of document was made through the exercises after they have finished using Compound Chunk to test their understanding. Worksheets are given to each of the pupils at the end of the sessions as a test of improvement.

Next, in analysing those interviews, a transcription from the audio interview is formed. Then, an open coding is made as to categorize the data into manageable segments as recommended by (Fraenkel et al. 2015). Each transcription is read several times and some code categories are worked out based on what the pupils had answered. It was easier to reread and analysed each interview. In order to find a category or code in a data, Goh (2012) suggested several solutions like searching the transcription for repeated words, simplify a sentence or phrase by finding the keyword, make a comparison, and highlight the keywords then reread the data for further analysis.

\section{Finding and Discussion}

The findings of the research were written based on the two research questions. All the data were collected based on three data collection method. 
The massive changes in all participants' score after the intervention had paved the way towards showing significance answer to the research questions. It could be concluded that the research participants' spelling compound nouns skill did experience the improvement.

Table 1

Instruments used based on the Research Questions

\begin{tabular}{|c|c|}
\hline Research Questions & Instruments Used \\
\hline $\begin{array}{l}\text { Research Question } 1 \\
\text { 1. Can the pupils' spelling be } \\
\text { improved by using the } \\
\text { Compound Chunk via } \\
\text { Telegram Autobot? }\end{array}$ & Document analysis \\
\hline \multirow{2}{*}{$\begin{array}{l}\text { Research Question } 2 \\
\text { 2. To what extent the } \\
\text { Compound Chunk via } \\
\text { Telegram Autobot helps in } \\
\text { improving pupil' spelling } \\
\text { skill of compound nouns? }\end{array}$} & Observation \\
\hline & Interview \\
\hline
\end{tabular}

Research Question 1: Can the pupils' spelling be improved by using the Compound Chunk via Telegram Autobot?

\section{Document Analysis}

Analysis of document was made through the Compound Chunk Telegram Autobot Game played throughout the process of intervention. There were two level of Compund Chunk Telegram Autobot game given during the session and three exercises sheets given to each of the pupils at the end of the sessions as a test of improvement. As to see pupils' improvement in spelling compound nouns, researchers prepared and analysed the documents using Spelling Improvement Checklist before and after the intervention.

The first analysis that can be made was, pupils' could not spell most of the compound nouns words correctly before the intervention took place. The score showed improvement between the before intervention and after intervention 
International Journal of Academic Research in Progressive Education and Development Vol. 8, No. 1, 2019, E-ISSN: $2226-6348$ @ 2019 HRMARS

Table 2

Comparison of participants' results before and after the intervention.

\begin{tabular}{|c|c|c|}
\hline RESEARCH PARTICIPANT & $\begin{array}{l}\text { BEFORE } \\
\text { INTERVENTION }\end{array}$ & $\begin{array}{l}\text { AFTER } \\
\text { INTERVENTION }\end{array}$ \\
\hline $\begin{array}{l}\text { S1 (Urban, Bandar Baru } \\
\text { Bangi, Selangor 1) }\end{array}$ & $2 / 15$ & $15 / 15$ \\
\hline S2 & $1 / 15$ & $14 / 15$ \\
\hline S3 & $2 / 15$ & $15 / 15$ \\
\hline S4 & $4 / 15$ & $15 / 15$ \\
\hline S5 & $4 / 15$ & $15 / 15$ \\
\hline S6 & $2 / 15$ & $15 / 15$ \\
\hline S7 & $3 / 15$ & $15 / 15$ \\
\hline S8 & $5 / 15$ & $14 / 15$ \\
\hline s9 & $4 / 15$ & $15 / 15$ \\
\hline S10 & $3 / 15$ & $15 / 15$ \\
\hline M1 (Urban, Alor Gajah, & $2 / 15$ & $13 / 15$ \\
\hline Melaka 1) & $2 / 15$ & $14 / 15$ \\
\hline M2 & $5 / 15$ & $15 / 15$ \\
\hline M3 & $3 / 15$ & $15 / 15$ \\
\hline M4 & $3 / 15$ & $15 / 15$ \\
\hline M5 & $1 / 15$ & $14 / 15$ \\
\hline M6 & $0 / 15$ & $12 / 15$ \\
\hline M7 & $3 / 15$ & $15 / 15$ \\
\hline M8 & $0 / 15$ & $13 / 15$ \\
\hline M9 & $4 / 15$ & $14 / 15$ \\
\hline M10 & & \\
\hline $\begin{array}{l}\text { P1 (Urban, Seri Iskandar, } \\
\text { Perak 1) }\end{array}$ & $3 / 15$ & $15 / 15$ \\
\hline P2 & $4 / 15$ & $15 / 15$ \\
\hline P3 & $3 / 15$ & $14 / 15$ \\
\hline P4 & $3 / 15$ & $15 / 15$ \\
\hline P5 & $2 / 15$ & $14 / 15$ \\
\hline P6 & $1 / 15$ & $12 / 15$ \\
\hline P7 & $2 / 15$ & $13 / 15$ \\
\hline P8 & $4 / 15$ & $14 / 15$ \\
\hline P9 & $3 / 15$ & $15 / 15$ \\
\hline P10 & $2 / 15$ & $15 / 15$ \\
\hline
\end{tabular}

Based on the findings above, the score showed improvement between the before intervention and after intervention. As we can see, all of them showed vast improvement in their spelling exercises. Respondent S1 managed to get full score during the final exercise compared to the spelling bee test before the intervention where he could only obtained 2 correct answers. This went the same with Research Participant P1 whom scores was perfect as he managed to get full 
marks compared to the first spelling test. As for Respondent M9, he managed to get score of thirteen out of fifteen during the final assessment. All of them showed vast improvement in their spelling exercises. It could be concluded that the research participants' spelling compound nouns skill did experience the improvement.

Research Question 2: To what extent the Compound Chunk via Telegram Autobot helps in improving pupils' spelling skill of compound nouns?

\section{Observation}

Observation was a fundamental and highly important method to all qualitative inquiry. It was the recommended data that can be used in collecting the data. Researchers used an amended checklist as observation of the pupils' performances. This checklist helped to find the improvement of the pupils' along the session. It was used to monitor the pupils' attitude and achievements of the pupils' themselves. Throughout this research, researchers found a pupil who could not give fully attention to the intervention and tended to disturb his friends. Fortunately, all of them were performed well along the sessions especially when teachers gave rewards for their effort. The checklist will be tick or cross for before intervention and after intervention. The accumulated data will be tabulated in a table.

Table 3

Observation Checklist

Aspects

Behaviour and attitude

1. Talking with other pupils

2. Disturbing other pupils

3. Good discipline

4. Listen attentively to teacher's $X$ explanation

5. Respond to teacher's questions

6. Show appropriate body language to $X$ show understanding

7. Asking questions

\section{Achievement}

8. Improving in spelling compound $X \quad X \quad X$ nouns

9. Recognize the pictures

10. Complete the tasks given

Pupils' participation

11. Actively involved

12. Shy

12. Uncontrolled

$\begin{array}{lll}x & x & x\end{array}$

$x \quad x$

X $\quad x$

Before After

$\begin{array}{llllll}\text { S1 } & \text { M1 } & \text { P1 } & \text { S1 } & \text { M1 } & \text { P1 }\end{array}$

\begin{tabular}{llllll}
1 & $x$ & 1 & 1 & 1 & 1 \\
\hline & 1 & $x$ & $x$
\end{tabular}

$\begin{array}{llllll}/ & x & / & x & x & x\end{array}$

$x \quad / \quad x \quad / \quad / \quad /$

$\begin{array}{lllll}x & x & / & / & / \\ x & x & / & / & / \\ x & / & / & / & /\end{array}$


The behaviour and attitudes of the research participants S1 before implementing the game was not good because he tended to talk to his friends while I delivering the introduction session but when I showed and implemented the game, this participant S1 started to show a good discipline in the session. The research participants $M 1$ who was introvert and passive before the intervention showed an improvement where he interacted and participated in the activities planned afterwards. While participant P1 showed a good improvement and behaviours until the end of session.

\section{Interview}

The findings from the score are also supported with interviews. For this research, an after semi structured interview session was conducted. Due to their lack of proficiency in English, the interview was carried out using Malay. The data of the interview were taken from all research participants. The excerpts from the interview were transcribed to support the findings as depicted in Table 4.

\section{Table 4}

Emerging theme from the interview data

\begin{tabular}{|l|l|l|l|}
\hline No & Themes & Frequency & Percentage (\%) \\
\hline 1 & Can Spell the words & 34.0 & 24.3 \\
\hline 2 & It was fun words by the & 40.0 & 28.6 \\
\hline 3 & $\begin{array}{l}\text { Recognise the } \\
\text { colourful pictures }\end{array}$ & 25.0 \\
\hline 4 & The quiz is interesting & 31.0 & 22.1 \\
\hline & Total & $\mathbf{1 4 0}$ & $\mathbf{1 0 0}$ \\
\hline
\end{tabular}


International Journal of Academic Research in Progressive Education and Development Vol. 8, No. 1, 2019, E-ISSN: 2226-6348 @ 2019 HRMARS

Table 5

Extract from three Interview questions after intervention

\begin{tabular}{|c|c|c|}
\hline & Questions & Code \\
\hline Teacher & $\begin{array}{l}\text { Do you like the Compound Chunk game played via } \\
\text { Telegram Autobot? Why? }\end{array}$ & \\
\hline Pupils S1 & Yes, I like it because it is interesting. & - Interesting \\
\hline Pupils M1 & Yes, I like it because it is fun. & - Fun \\
\hline Pupils P1 & I love it because the pictures are colourful. & - Colourful \\
\hline Teacher & $\begin{array}{l}\text { What is your feeling when you are able to spell } \\
\text { compound nouns correctly? }\end{array}$ & \\
\hline Pupils S1 & Happy because it is easy now & - Easy \\
\hline Pupils M1 & $\begin{array}{l}\text { I'm happy because I can recognize the compound } \\
\text { nouns by seeing pictures }\end{array}$ & - Recognize the words \\
\hline Pupils P1 & $\begin{array}{l}\text { Happy because I also can know common nouns too } \\
\text { not only compound nouns }\end{array}$ & - Know other nouns \\
\hline Teacher & $\begin{array}{l}\text { Do you think you getting better in spelling } \\
\text { compound nouns after been introduced to } \\
\text { Compound Chunk? }\end{array}$ & \\
\hline Pupils S1 & Yes, it does not take much time to spell anymore. & $\begin{array}{l}\text { Save time to spell } \\
\text { (easy) }\end{array}$ \\
\hline Pupils M1 & Getting cleverer because it simple now. & Simple \\
\hline Pupils P1 & $\begin{array}{l}\text { Yes, because I got many correct answers and it easy } \\
\text { to spell by looking at the pictures. }\end{array}$ & Help by looking at pictures \\
\hline
\end{tabular}

The intervention session had managed to shift their perception towards spelling activity. Participants gave positive opinions concerning the use of Compound Chunk via Telegram Autobot in improving spelling compound nouns. They mentioned that the game was fun, colourful, easy to remember, simple and even saving time for them to spell. The effectiveness of the intervention can be proven throughout the code of what the participant's response that already been put as keywords of the unstructured interviews. Hence, it shows that the Compound Chunk via Telegram Autobot Quiz gave positive impact to the pupils and as well helped them in improving spelling skill of compound nouns.

Looking back at their scores before and after the session, it clearly supported the perception that this intervention had improved their spelling skill even though they still need teacher's supervision on their spelling as they tended to make careless mistakes but that could not disrupt the reliability of the data of their improvement considering they had improved a lot compared to the time before the intervention started.

Learning with colorful pictures had various advantages in dealing with memory retention. Wichman, Sharpe and Gegenfurtner (2012) as cited in Mariam and Muhammad Faiz (2013) supported the statement by indicating that the colour acts as a powerful information channel to the human cognitive system, and has been found to play a significant role in enhancing memory performance. Hence using this Pictoword Orihon Game book, which I incorporated with various colourful pictures, I could say that it helped them in improving their spelling skill in terms of 
reproducing the spelling by looking at the pictures to trigger their memory. Besides they were now able to write the spelling words as well as spelling the words orally too.

The goal of this study was to determine whether the pupils' spelling be improved by using the Compound Chunk via Telegram Autobot. The result showed an improvement in the score of spelling exercise before the intervention and after the intervention. It appeared that students found the Compound Chunk via Telegram Autobot Quiz equally educational and enjoyable. Our findings suggest that using messaging apps in class could serve as a useful pedagogical to enhance student learning.

\section{Implication and Conclusion}

The findings indicated that there had been an improvement in the participants' spelling performance after the intervention and gave positive opinions concerning the use of the quiz. In conclusion, the quiz can be extended by adding more words of various contents benefited on the use of messaging apps as 21st Century teaching aid in written spelling.

From the findings, there are two major implications can be derived. Firstly, language learning difficulty among students can be solved by manipulating the available technologies. Since using technologies has become part of todays' daily life, students do not find any difficulty in using the apps and completing the quiz in the Compound Chunk. The applications of mobile technology for learning purposes are boundless (Muslimin, Nordin, Mansor \& Yunus, 2017). Therefore, it is the teachers that play the crucial role in designing activities and lesson plans that suit the students' interest and relevant to their living environment. Secondly, most of the students are visual learners. The students are learning better when the materials are something that they can see. Yunus (2013) mentioned that the use of visual aids helped the students to visualised clearly. So in order to maximize the learning experience, teacher should integrate lesson with more visual type media materials.

Reflected from the research question 1 "Can the pupils' spelling be improved by using the Compound Chunk via Telegram Autobot?" After analysing the data, it is proven that the use of Compound Chunk via Telegram Autobot to teach spelling was a good technique to teach spelling unlike the traditional method where pupils were required to memorise but it was done by simply playing game. The pupils were no longer bound to the traditional method, which required them to memorise the word to spell correctly. Now, they can learn spelling through games that is enjoyable and at the same time more relaxing. Hence, the pupils would be able to learn better through this method.

On the other hand, to reflect from the research question 2 "To what extent the Compound Chunk via Telegram Autobot helps in improving pupils' spelling skill of compound nouns?" The use of Compound Chunk via Telegram Autobot did in fact increase the research participants' confidence level in when it comes to spelling. The pupils were no longer scared or nervous when it came to spelling. The pupils also could spell without mumbling or stuttering even when they were wrong. This accomplishment in line with Krashen's theory of second language acquisition as Krashen cited in Schutz (2014) claimed that low motivation, low self - esteem and debilitating anxiety can 
combine to raise the affective filter and form a 'mental block' that prevents comprehensible input from being used for acquisition.

In summary, the data suggest that the use of mobile technologies, in general, and mobile apps, specifically, in the classroom is enjoyable and enhances student learning. Teachers can use apps to develop innovative learner-centered activities and even adapt an activity to promote collaborative learning. With greater instructional training, teachers could also learn to develop their own apps to implement in their courses. As education moves toward a more learnercentered model and the popularity of mobile devices and downloadable apps continue to grow, teachers can use this as an opportunity to enhance teaching and learning in their classroom.

This study analyze the data collected qualitatively so it would be advantageous for researchers in other contexts to replicate a similar project or use the findings to design a mixed method or quantitative study. Secondly, the participants of this study consist of 30 primary school students; further studies can be conducted with more participants and higher-level students. Thirdly, this study was set in specific context where compound nouns were used as the quiz questions in the telegram autobot. Studies can be done with other language component would be beneficial as well as studies using other mobile applications. The levels in the application could also be added as well as rewarding the pupils in a form of virtual tokens that they can collect to increase pupils' interest.

\section{Corresponding Author}

Melor Md Yunus (PhD), Department of Research and Innovation, Faculty of Education, Universiti Kebangsaan Malaysia, 43600 UKM, Bangi, Selangor, Selangor Darul Ehsan, Malaysia.

Email:melor@ukm.edu.my

\section{References}

Bennett, A. (2011). The Role of Play and Games in Learning. the 33rd Earl V. Pullias Lecture. University of South California (USC) USA.

Kurikulum, B.P. (2011). Dokumen Standard Kurikulum Sekolah Rendah: Bahasa InggerisTahun 4 [Standard Curriculum Document: English Year 4]. Putrajaya: Kementerian Pelajaran Malaysia.

Berninger, V. (2002). Teaching spelling and composition alone and together: Implications for the simple view of writing. Journal of Educational Psychology, 94(2), pp.291-304.

Bowen, G. (2009). Document Analysis as a Qualitative Research Method. Qualitative Research Journal, 9(2), 27-40. http://dx.doi.org/10.3316/arj0902027

Cruz, Y., Boughzala, I., \& Assar, S. (2012). Opportunities and obstacles for mobile learning in a Business School. 2012 International Conference On Communications And Information Technology (ICCIT). doi: 10.1109/iccitechnol.2012.6285824 
Sigridur, D. (2012). The Use of Games in The Language Classroom. Retrieved from http://skemman.is/stream/get/1946/6467/13457/1/Sigridurdogg2010.pdf.

Eppard, J., Nasser, O., \& Reddy, P. (2016). The Next Generation of Technology: Mobile Apps in the English Language Classroom. International Journal Of Emerging Technologies In Learning (ljet), 11(04), 21. DOI: 10.3991/ijet.v11i04.5293

Fraenkel, J. R., Wallen, N. E. \& Hyun, H. H. (2015). How to design and evaluate research in education (9th ed.). New York: McGraw-Hill Education.

Gardner, H. (2004). The disciplined mind: What all students should understand. New York: Simon \& Schuster.

Ghaemi, F. \& Rafi, F. (2018). The Impact of Visual Aids on the Retention of English Word Stress Patterns. International Journal Of Applied Linguistics And English Literature, 7(2), 225. doi: 10.7575/aiac.ijalel.v.7n.2p.225

Goh, L. H. (2012). A practical Guide to Writing Your Action Research. Puchong, PG : Penerbitan Multimedia

Gower, R., Phillips, D., \& Walters, S. (2007). Teaching practice handbook. Oxford: Macmillan.

Harmer, J. (2007). The practice of English language teaching. Harlow, England: Pearson Longman.

Johnson, R. W. (2008). Qualitative research guidelines project. Retrieved from P.O. Box 2316 College Road East and Route 1 Princeton, NJ 08543: http://www.qualres.org/HomeObse3594.html.

Lan, Y. F., \& Sie, Y. S. (2010). Using RSS to support mobile learning based on media richness theory. Computers \& Education, 55 (2), 723-732

Lauricella, S., \& Kay, R. (2013). Exploring the use of text and instant messaging in higher education. Research in Learning Technology, Vol. 21, 19061

Lin, L. (2017). An Analysis of Conceptions of Learning English Among College Students in China. Sino-US English Teaching, 14(4). doi: 10.17265/1539-8072/2017.04.004

Marshall. (2006). Data Collection Method. Retrieved from http://www.sagepub.com/upmdata/10985 Chapter 4.pdf.

Miller, L., \& Pound, L. (2010). Theories and Approaches to Learning in the Early Years. London: SAGE Publications 
Muslimin, M., Nordin, N., Mansor, A., \& Yunus, M. (2017). THE DESIGN AND DEVELOPMENT OF MobiEko: A MOBILE EDUCATIONAL APP FOR MICROECONOMICS MODULE. Malaysian Journal Of Learning And Instruction, (Special Issues), 221-255. Retrieved from http://mjli.uum.edu.my/images/specialissue/2017/A10-ms221-255.pdf

Pushkash, A. (2016). I, Chatterbot: Why Virtual Conversational Partners are on Trend Again. Retrieved from http://news.ifmo.ru/en/science/it/news/5888/

Roos, S. (2016). CHATBOTS IN EDUCATION A passing trend or a valuable pedagogical tool?. Retrieved from https://pdfs.semanticscholar.org/533e/bc0255c36749e1f46b8d3662464d6ee5d4f0.pdf

Schutz, R. (2014). Stephen Krashen's Theory of Second Language Acquisition. Retrieved from http://sk.com.br/sk-krash.html

Westwood, P. (2014) Teaching Spelling: exploring commonsense strategies and best practices. New York, NY: Routledge

Yunus, M. M., Salehi, H., \& John, S. A. (2013). Using visual aids as a motivational tool in enhancing students" interest in reading literary text. Recent Advances in Educational Technologies, 114-17. Retrieved from http://arxiv.org/ftp/arxiv/papers/1305/1305.6360.pdf 